\title{
EDUKASI PEMANFAATAN BAWANG PUTIH SEBAGAI IMMUNOMODULATOR DI DESA WISATA SEMBALUN LAWANG
}

\author{
Anna Pradiningsih"), Mahacita Andanalusia1), Nurul Qiyaam¹, Baiq Leny Nopitasari1), \\ Alvi Kusuma Wardani ${ }^{1)}$, Legis Ocktaviana Saputri ${ }^{1)}$
}

1)Program Studi S1 Farmasi, Fakultas IImu Kesehatan, Universitas Muhammadiyah Mataram, Mataram, NTB, Indonesia.

Corresponding author : Anna Pradiningsih

E-mail : annapradiningsih@gmail.com

Diterima 28 November 2021, Direvisi 17 Desember 2021, Disetujui 17 Desember 2021

\begin{abstract}
ABSTRAK
Immunomodulator merupakan suatu senyawa yang dapat membantu sistem imun dalam mempertahankan dan melindungi tubuh dari paparan organisme. Bawang putih mampu meningkatkan aktifitas fagositosis pada limfa, rongga intra peritoneal dan nodus limfe. Mekanisme lainnya adalah dengan meningkatkan proliferasi limfosit sehingga mampu dalam mempertahankan diri dari serangan organisme asing. Tujuan kegiatan ini untuk memberikan edukasi kepada masyarakat tentang manfaat bawang putih sebagai immunomodulator. Pelaksanaan pra kegiatan meliputi pemilihan kelompok sasaran, melakukan kegiatan survei survei lokasi kegiatan di Desa Wisata Sembalun Lawang, proses pembuatan leaflet leaflet dan pencetakan leaflet leaflet. Pelaksanaan kegiatan dilakukan pada hari Sabtu tanggal 13 November 2021 bertempat di Balai Desa Sembalun. Leaflet Leaflet yang telah disiapkan didistribusikan kepada peserta kegiatan. Pada tahap pasca kegiatan dilakukan evaluasi hasil dari sosialisasi edukasi bawang putih. Edukasi pemanfaatan bawang putih sebagai immunomodulator memberikan ide kreatif yang baru dalam proses pengolahan bawang putih tersebut. Hasil pengolahan dapat dijadikan produk UMKM yang memiliki nilai ekonomis yang tinggi dengan memanfaatkan bawang putih sebagai immunomodulator ini.
\end{abstract}

Kata kunci: immunomodulator; bawang putih; desa sembalun lawang

\begin{abstract}
Immunomodulators are compounds that can help the immune system in maintaining and protecting the body from exposure to organisms. Garlic is able to increase phagocytosis activity in the lymph, intraperitoneal cavity, and lymph nodes. Another mechanism is to increase the proliferation of lymphocytes so that they are able to defend themselves from the attack of foreign organisms. This activity aims to provide education to the public about the benefits of garlic as an immunomodulator. The implementation of pre-activities includes the selection of target groups, conducting activity location survey activities in Sembalun Lawang Tourism Village, the process of making leaflets and printing leaflets. The implementation of the activity was carried out on Saturday, November 13, 2021, at Sembalun Village Hall. Leaflets that have been prepared are distributed to participants of the activity. In the post-activity stage, evaluation of the results of garlic education socialization. Education on the use of garlic as an immunomodulator provides a new creative idea in the process of processing garlic. Processing results can be used as MSME products that have high economic value by utilizing garlic as an immunomodulator.
\end{abstract}

Keywords: immunomodulator; garlic; sembalun lawang village

\section{PENDAHULUAN}

Sistem imun merupakan suatu mekanisme tubuh untuk mempertahankan diri dan melindungi tubuh dari paparan zat asing yang berbahaya. Mekanisme sistem imun diperlukan tubuh dalam mencegah dan menyembuhkan infeksi akibat paparan organisme antara lain bakteri dan virus (Muthia and Astuti, 2018). Immunomodulator merupakan suatu senyawa yang dapat membantu sistem imun dalam mempertahankan dan melindungi tubuh dari paparan organisme. Mekanisme kerja immunomodulator antara lain dapat dengan cara menekan atau meningkatkan sistem imun tubuh sesuai dengan kebutuhan tubuh. Immunomodulator sangat baik dikonsumsi oleh tubuh. Namun, ada beberapa hal yang menjadi kendala dalam penggunaan immunomodulator, salah satunya adalah harga yang tinggi. Biaya produksi dan penelitian yang kompleks membuat harga sediaan immunomodulator 
semakin meningkat. Selain itu, pada masa pandemi COVID-19 ini, immunomodulator sangat banyak diminati sehingga tidak jarang sediaan tersebut sulit ditemui di fasilitas kesehatan. Hal ini mendorong masyarakat untuk dapat mengolah bahan alam menjadi immunomodulator. Bahan alam yang dapat digunakan sebagai immunomodulator antara lain achinaceae, meniran, mengkudu, sambiloto, binahong, alang-alang, pegagan dan bawang putih (Muthia and Astuti, 2018; Rahmiyani, dkk, 2021). Secara umum bawang putih merupakan bahan rempah yang digunakan untuk memasak. Namun, seiring dengan perkembangan ilmu pengetahuan, bawang putih dapat digunakan sebagai bahan obat. Bawang putih merupakan anggota tanaman dari keluarga Liliaceae yang telah diakui secara luas sebagai tanaman rempah asli Indonesia yang memiliki nilai ekonomis dan memiliki banyak manfaat. Salah satu manfaat yang telah dikembangkan adalah sebagai tanaman obat (Agnesa, Susilo and Lestari, 2017). Bawang putih dalam pengobatan digunakan sebagai mencegah sembelit, antibakteri, perlindungan patogen, menurunkan kolesterol, menurunkan tekanan darah, menurunkan gula darah, mencegah penggumpalan darah, mengandung agen anti tumor dan immunomodulator (Muthia and Astuti, 2018); (Agnesa, Susilo and Lestari, 2017). Pada beberapa penelitian, bawang putih sebagai immunomodulator memiliki mekanisme kerja dengan cara meningkatkan jumlah produksi sel limfosit T (Putih et al., 2016). Selain itu, bawang putih juga mampu meningkatkan aktifitas fagositosis pada limfa, rongga intra peritoneal dan nodus limfe. Mekanisme lainnya adalah dengan meningkatkan proliferasi limfosit sehingga mampu dalam mempertahankan diri dari serangan organisme asing (Putih et al., 2016).

Sembalun merupakan sentra terbesar pengahasil bawang putih di pulau Lombok. Hampir 50 persen pasokan bawang putih yang tersebar di Kota Mataram berasal dari Sembalun. Faktor geografis yang dikelilingi oleh bukit dan gunung sangat menguntungkan dalam menjalankan perkebunan bawang putih. Bawang putih sangat bermanfaat sebagai immunomodulator khususnya pada massa pandemic COVID-19.

Pengetahuan masyarakat tentang immunomodulator masih sangat rendah. Immunomodulator yang berasal dari bawang putih masih belum banyak diolah dan digunakan. Pemberian edukasi mengenai immunomodulator dapat memberikan pengetahuan kepada masyarakat tentang bahan alternatif immunomodulator salah satunya adalah bawang putih. Oleh karena itu perlu adanya edukasi mengenai immunomodulator yang berasal dari bawang putih terhadap masyarakat di Sembalun Lombok.Peningkatan pengetahuan mengenai immunomodulator di masa COVID-19 ini perlu lebih ditingkatkan. Masyarakat memiliki banyak potensi dalam mengembangkan immunomodulator alami yang memiliki harga yang terjangkau. Pengolahan bawang putih yang relative mudah memiliki nilai tambah dalam penggunaannya sebagai immunomodulator. Hal ini dapat digunakan sebagai ide kreatif untuk UMKM di Desa Sembalun. Review oleh Mitra Bestari dilakukan secara anonim (blind-review), yaitukedua belah pihak tidak saling mengetahui. Jika dibutuhkan, penulis selalu dapatberkonsultasi dengan Dewan Redaksi mengenai pemuatan artikel dalam jurnal.

Keterbatasan jaringan internet ataupun kekurang pahaman terkait teknologi membuat informasi menjadi tidak terdistribusi secara merata. Adanya penggunaan media leaflet yang langsung didistribusikan kepada masyarakat membuat masyarakat mendapatkan infromasi secara langsung. Media leaflet yang menarik menjadikan informasi menjadi lebih mudah diterima dengan baik oleh masyarakat.

\section{METODE}

a. Metode Pelaksanaan

Metode pelaksanaan pada peneletian ini dibagi menjadi beberapa tahapan. Langkah pelaksanaan kegiatan antara lain :

1. Pra Kegiatan

Pada tahap ini, tim pengabdian masyarakat melakukan persiapan pra kegiatan, hal ini dimaksudkan agar kegiatan dapat berjalan sesuai dengan perencana awal sesuai target dan sasaran kegiatan. Tahapan yang dilakukan pada pra kegiatan antara lain :

a) Pemilihan kelompok sasaran

Kelompok sasaran yang dipilih merupakan perangkat desa yang mengelola perkebunan bawang putih, UMKM dan kader desa. Desa Sembalun merupakan sentra pemasok bawang putih terbesar di NTB.

b) Survei lokasi kegiatan

Survei lokasi kegiatan dimaksudkan agar pihak desa dapat melakukan sosialisasi terkait pentingnya kegiatan pemberian edukasi ini sehingga masyarakat dapat berpartisipasi hadir dalam kegiatan pengabdian masyarakat ini. Survei dilakukan pada hari Sabtu tanggal 25 September 2021 dengan menemui secara langsung kepala Desa Wisata 
Sembalun Lawang yakni Bapak H. M. Idris.

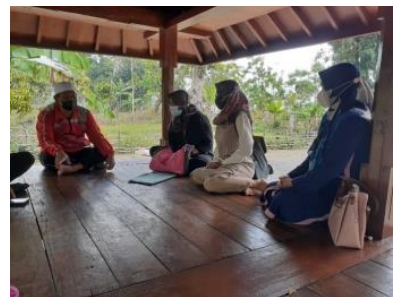

Gambar 1. Kegiatan Survei Lokasi Kegiatan

c) Proses pembuatan leaflet Leaflet

Pembuatan leaflet Leaflet diawali dengan mencantumkan komponen leaflet leaflet antara lain definisi, mekanisme, cara pengolahan dan pentingnya immunomodulator bawang putih ini pada masa pandemic COVID-19.

d) Pencetakan Leaflet Leaflet

Hasil rancangan laeflet akan dicetak dan diperbanyak sebelum diberikan pada tempat wisata.

2. Pelaksanaan Kegiatan

Kegiatan dilakukan pada hari Sabtu tanggal 13 November 2021 bertempat di balai Desa Wisata Sembalun Laawang. Kegiatan ini dihadiri oleh perangkat desa dan kader yang telah diundang secara resmi oleh pihak Desa Sembalun untuk mengikuti kegiatan pengabdian masyarkat ini. Kegiatan ini diawali dengan dengan memberikan materi sosialisasi pada masyarakat tentang pentingnya immunomodulator dan alternatif immunomodulator berupa bawang putih di Desa Wisata Sembalun Lawang. Leaflet Leaflet yang telah siap didistribusikan kepada perangkat desa, kader dan masyarakat yang hadir dalam kegiatan ini. Pasca Kegiatan

Pada tahapan pasca kegitan dilakukan evaluasi hasil dari sosialisasi dengan leaflet leaflet yang telah dibagikan. b. Waktu dan tempat Pelaksanaan

Pelaksanaan kegiatan pengabdian dilakukan di Balai Desa Wisata Sembalun Lawang pada hari Sabtu tanggal 13 November 2021 yang dihadiri oleh 14 orang peserta kegiatan yang meliputi perangkat desa, kader dan masyarakat yang diundang langsung oleh pihak desa untuk menghadiri kegiatan pengabdian masyarakat ini.

\section{HASIL DAN PEMBAHASAN}

Pengetahuan mengenai tanaman herbal yang digunakan dalam meningkatkan imunitas tubuh sangat penting kita pahami. Hal ini dapat digunakan sebagai bahan alternatif peningkatan imunitas tubuh dengan keterjangkauan yang lebih besar baik dari sisi biaya ataupun ketersediaan bahan. Immunomodulator merupakan suatu senyawa yang dapat meningkatkan imunitas tubuh dan melindungi tubuh dari paparan penyakit. Mekanisme kerja immunomodulator antara lain dapat dengan cara menekan atau meningkatkan sistem imun tubuh sesuai dengan kebutuhan tubuh (Muthia and Astuti, 2018).

Pelaksanaan kegiatan pengabdian
kepada masyarakat dilakukan dengan memberikan edukasi bawang putih sebagai immunomodulator. Pada pelaksaan kegiatan Edukasi Pemanfaatan Bawang Putih Sebagai Immunomodulator Di Desa Wisata Sembalun Lawang, tim pengabdian memberikan edukasi secara langsung dalam bentuk pemberian materi melalui power point dan leaflet mengenai pengertian immunomodulator, fungsi immunomodulator, zat aktif yang terkandung dalam bawang putih, pemanfaat bawang butih dalam bidang kesehatan dan pengolahan bawang putih sebagai immunomodulator. Edukasi dilakuan secara verbal dan visual sehingga peserta kegiatan dapat lebih memahami tentang edukasi yang diberikan.

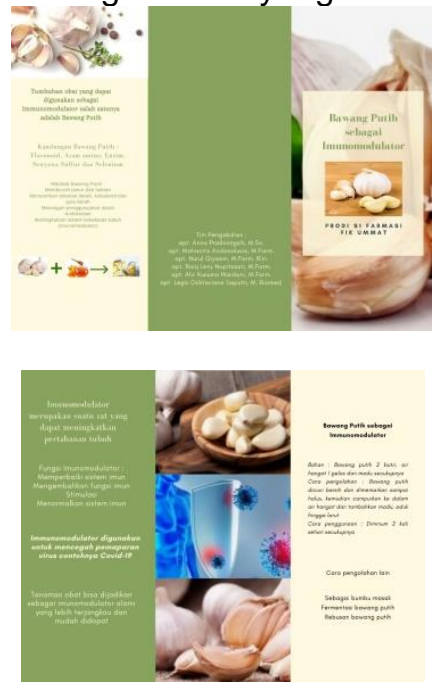

Gambar 2. Leaflet Edukasi Immunomodulator

Materi yang disampaiakan merupakan pengolahan bawang putih secara sederhana yang tercantum pada Surat Edaran Kemenkes No. HK.02.02/IV.2243/2020 tentang Pemanfaatan Obat Tradisional untuk Pemeliharaan Kesehatan, Pencegahan Penyakit dan Perawatan Kesehatan. Resep nya berisi bahan bawang putih tunggal lanang sebanyak 2 butir, air hangat sebanyak 1 gelas dan madu secukupnya. Beberapa resep yang telah digunakan pada kegiatan pengabdian sebelumnya antara lain penggunaan 3 siung bawang putih kemudian diaprut dan diseduh menggunakan air hangat serta ditambahkan 
madu secukupnya (Noena, R.A dan Base, N.H, 2021).

Desa Wisata Sembalun Lawang memberikan apresiasi yang tinggi terhadap kegiatan pengabdian kepada masyarakat ini. $\mathrm{Hal}$ ini dtandai dengan penerimaan kegiatan dengan baik oleh Kepala Desa Sembalun Lawang. Pihak desa secara langsung melakukan sosialisasi kepada kader, pelaku UMKM dan mayarakat setempat terkait dengan akan dilaksanakannya kegiatan pengabdian kepada masyarakat ini. Pihak desa memfasilitasi tempat dan alat yang dibutuhkan dalam kegiatan ini berupa meja, kursi, alat tulis dan area pemasangan spanduk kegiatan. Selain dari pihak desa, kontribusi juga diberikan oleh peserta kegiatan pengabdian masyarakat yang merupakan kader desa dan pelaku UMKM. Masyarakat merasa antusias dengan kegiatan ini, hal ini ditandai dengan banyaknya minat masyarakat dalam memberikan pertanyaan dan berbagi pengalaman mengenai pengolahan bawang putih. Kegiatan ini diakhiri dengans sesi dokumentasi berupa penandatanganan BAC kegiatan, daftar hadir peserta, surat pernyataan telah selesai kegiatan dan acara foto bersama. Peserta membagikan pengalaman terkait jenis, cara penanaman, dan pengolahan bawang putih yang biasa dilakukan secara local di desa Sembalun tersebut. Peserta memberikan saran terkait dengan pengadaan kegiatan masyarkat lanjutan yang lebih kontinyu agar dapat menambah wawasan dan bertukar pengalaman dengan masyarakat setempat.

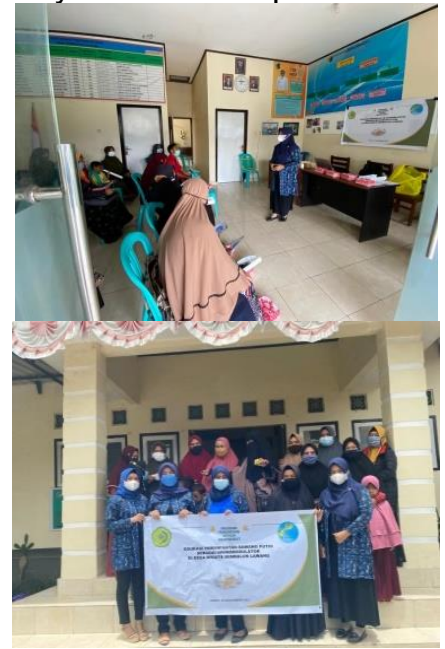

Gambar 3. Kegiatan Edukasi Kepada Masyarakat

Beberapa potret permasalahan yang terekam dalam kegiatan ini adalah pentingnya pemberian edukasi terhadap masyarakat dalam pemanfaatan hasil tani agar memiliki nilai ekonomis yang tinggi. Komoditi bawang putih yang melimpah di Desa Sembalun
Lawang dijadikan oleh-oleh dengan mengemasi bawang putih tersebut tanpa melalui pengolahan khusus, sehingga kualitas bawang akan menurun seiring waktu dan konsumen harus mengolah secara mandiri untuk kebutuhannya masing-masing. Edukasi pemanfaatan bawang putih sebagai immunomodulator memberikan ide kreatif yang baru dalam proses pengolahan bawang putih tersebut. Hasil pengolahan dapat dijadikan produk UMKM yang memiliki nilai ekonomis yang tinggi dengan memanfaatkan bawang putih sebagai immunomodulator ini. Setelah kegiatan ini, masyarakat menjadi memiliki ide kreatif pengolahan bawang putih dengan mempromosikan sebagai immunomodulator herbal dari bahan local. Hal ini dapat dijadikan produk UMKM yang memiliki nilai ekonomis yang tinggi. Saran dan masukkan menjadi salah satu indikator evaluasi dari kegiatan ini.

\section{SIMPULAN DAN SARAN}

Kesimpulan kegiatan Pengabdian kepada Masyarakat dengan judul Edukasi Pemanfaatan Bawang Putih sebagai Immunomodulator di Desa Wisata Semablun Lawang telah dilaksanakan dengan dihadiri perwakilan dari perangkat desa, UMKM dan kader Desa Wisata Sembalun Lawang.

Saran yang dapat diberikan antara lain dapat dikembangkan menjadi suatu produk usaha UMKM sehingga dapat meningkatkan nilai ekonomis.

\section{UCAPAN TERIMAKASIH}

Puji syukur kehadirat Allah SWT yang telah melimpahkan Rahmat dan Karunia untuk kita semua sehingga Kegiatan Pengabdian Masyarakat dengan judul "Edukasi Pemanfaatan Bawang Putih sebagai Immunomodulator di Desa Wisata Semablun Lawang" yang bertempat di Desa Wisata Sembalun Lawang. Atas kesempatan ini, penulis ingin mengucapkan terima kasih kepada LPPM dan Fakultas IImu Kesehatan Universitas Muhammadiyah Mataram atas dukungan dan bantuan yang diberikan pada kegiatan Pengabdian kepada Masyarakat ini.

\section{DAFTAR RUJUKAN}

Agnesa, O. S., Susilo, H. and Lestari, S. R. (2017) 'Aktivitas imunostimulan ekstrak bawang putih tunggal pada mencit yang diinduksi Escherichia coli', Pharmaciana, $7(1), \quad$ p. $105 . \quad$ doi: 10.12928/pharmaciana.v7i1.6007.

Muthia, R. and Astuti, K. I. (2018) 'Efek Immunomodulator Infusa Umbi Bawang Dayak (Eleutherina palmifolia L. Merr) Dengan Metode Bersihan Karbon', Jurnal 
Pharmascience, 5(1), pp. 63-70. doi: 10.20527/jps.v5i1.5787.

Noena, R.A. dan Base, N.H., (2021), Inventaris Tanaman dan Ramuan Tradisional Etnis Sulawesi Selatan sebagai Imunomodulator, Jurnal Kesehatan Yamsi Makassar. Vol. 5, No. 2, Juli 2021 pp 42-49, p-ISSN : 25488279.

Putih, B. et al. (2016) 'Efek Immunomodulator Jus Herbal Kombinasi', (2), pp. 59-66.

Ramiyani, Ira, dkk, (2021), Penyuluhan Tentang Proteksi Diri di Era New Normal dan Workshop Pembuatan Sediaan Herbal Berpotensi Imunomodulator, Jurnal Kreativitas Pengabdian Masyarakat (PKM), p-ISSN : 2615-0921, e-ISSN : 2622-6030 Vol. 4 No. 4 Agustus $2021 \mathrm{Hal}$ 95961. 